\title{
Biosynthesis of Polyhydroxyalkanoates from 1,3-Propanediol by Chromobacterium sp.
}

\author{
Hiroshi KimUra, Tomikazu Yamamoto, and Kenji IwaKURA \\ Department of Polymer and Science, Faculty of Engineering, Yamagata University, \\ Yonezawa, Yamagata 992-8510, Japan
}

(Received February 7, 2002; Accepted July 27, 2002)

\begin{abstract}
Chromobacterium sp. isolated from a river soil produced blend of a copolyester consisting of 3hydroxybutanoic acid (3HB) and 3-hydroxypropionic acid (3HP) units and copolyester consisting of the saturated 3hydroxyalkanoic acid (3HA) units of even carbon number $\mathrm{C} 4$ to $\mathrm{C} 14$ in addition to two unsaturated 3HA units [3hydroxy-5-cis-dodecenate (3H5DD) and 3-hydroxy-7-cis-tetradecenoate (3H7TD)] when cultivated on 1,3-propanediol (1,3-PD) as the sole carbon source under nitrogen-free conditions. The copolyesters with 3HP unit have up to $6 \mathrm{~mol} \%$ $3 \mathrm{HP}$ fractions, the number average molecular weight $\left(M_{\mathrm{n}}\right)$ with up to $4.4 \times 10^{5}$, the melting temperature $\left(T_{\mathrm{m}}\right)$ of 148 $158^{\circ} \mathrm{C}$ and the glass transition temperature $\left(T_{\mathrm{g}}\right)$ of $2-4^{\circ} \mathrm{C}$. In cotrast, the medium-chain-length polyhydroxyalkanoates $\left(\mathrm{PHA}_{\mathrm{MCL}}\right)$ with even carbon number of C6-C14 monomer units have $\mathrm{ca} .60 \mathrm{~mol} \%$ 3-hydroxydecanoate (3HD) fraction as the most predominant component and less than $4 \mathrm{~mol} \%$ of $3 \mathrm{H} 5 \mathrm{DD}$ and $3 \mathrm{H} 7 \mathrm{TD}$ fractions as minor. The $M_{\mathrm{n}}, T_{\mathrm{m}}$ and $T_{\mathrm{g}}$ of $\mathrm{PHA}_{\mathrm{MCL}}$ were $c a .1 .2 \times 10^{5}, 53^{\circ} \mathrm{C}$ and $-45^{\circ} \mathrm{C}$, respctively.

KEY WORDS Biosynthesis / Poly(3-hydroxybutyric acid-co-3-hydroxypropionic acid) [P(3HBco-3HP)] / Medium-Chain-Length Polyhydroxyalkanoates $\left(\mathrm{PHA}_{\mathrm{MCL}}\right)$ / 1,3-Propanediol / Chromobacterium sp. /
\end{abstract}

Polyhydroxyalkanoates (PHAs) are bacterial storage compounds, which are produced and intracellularly deposited as granules in many bacteria in the presence of excess carbon source under restricted growth conditions. ${ }^{1}$ More than 150 different constituents of PHAs have been identified to date as different hydroxyalkanoic acids with 3-14 carbon atoms. ${ }^{2,3}$ Since these microbial polyesters are biodegradable thermoplastics and/or elastomers, they have attracted much attention as a new environmentally compatible materials. ${ }^{4,5}$ The PHA producing bacteria can be broadly divided into two groups. One group of bacteria including Ralstonia eutropha (formerly known as Alcaligenes eutrophus) produces short-chain-length PHA ( $\mathrm{PHA}_{\mathrm{SCL}}$ ) with C3-C5 monomer units, while the other group including Pseudomonas oleovolans, that is the fluorescent pseudomonads belonging to rRNA-homology-group I, produces medium-chain-length PHAs ( $\mathrm{PHA}_{\mathrm{MCL}}$ ) with C6-C14 monomer units. ${ }^{6,7}$ In general, bacterially produced copolymers of hydroxyalkanoic acids have a narrow distribution of copolymer composition, meaning that all of the chains in a copolymer have similar comonomer compositions. However, some bacterial copolyesters have been reported to be a mixture of several copolymers with different compositions. For example, the copolymers with 3-hydroxybutyric acid (3HB) and 4-hydroxybutyric acid (4HB) units produced by Ralstonia eutropha were shown to be a mixture of random copolymers with two different $4 \mathrm{HB}$ contents. ${ }^{8}$ The copolymers consisted of $3 \mathrm{HB}$ and 3- hydroxyvaleric acid (3HV) accumulated by Ralstonia eutropha were reported also to be mixtures of several copolymers with different $3 \mathrm{HV}$ contents. ${ }^{9}{ }^{10} \mathrm{Re}-$ cently, a few bacteria among the pseudomonads have been found to produce copolyesters consisting of 3hydroxybutyric acid (3HB) and medium-chain-length 3-hydroxyalkanoic acid (3HA) units ${ }^{11}$ or a blend of a $3 \mathrm{HB}$ homopolymer and a random copolymer [P(3HBco-3HA]. ${ }^{12}$ The latter pseudomonas strain accumulating two different polyesters in the same cell was suggested to possess two types of polyester synthases with different substrste specificities, that is, specific for $3 \mathrm{HB}$ and 3HA units, respectively, and these two types of polyester biosynthesis genes have been cloned and analyzed at the molecular level. ${ }^{13}$

In this study, we report that Chromobacterium strain produces a blend of copolyester consisting of $3 \mathrm{HB}$ and 3-hydroxypropionic acid (3HP) units and copolyester consisting of the saturated 3HA units of even carbon number $\mathrm{C} 4$ to $\mathrm{C} 14$ in addition to two unsaturated 3HA units [3-hydroxy-5-cis-dodecenate (3H5DD) and 3-hydroxy-7-cis-tetradecenoate (3H7TD)] when cultivated on 1,3-propanediol (1,3-PD) as the sole carbon source under nitrogen-free conditions. To our knowlege, this Chromobacterium sp. is the first strain to produce simultaneously $\mathrm{P}(3 \mathrm{HB}-c o-3 \mathrm{HP})$ and $\mathrm{PHA} \mathrm{ACL}_{\mathrm{MC}}$ from 1,3-PD. 1,3-PD can be also produced by microbial synthesis from glycerol as a by-product in the oleochemical industory. ${ }^{14}$ Recent study report a recombinant $E$. coli as a single microorganism that can con- 
vert directly glucose to $1,3-\mathrm{PD} .{ }^{15}$ Therefore, it is expected that 1,3-PD becomes one of renewable resources for making different "green" polymers. A few chemosynthesis of green polymers based on 1,3-PD have been reported, ${ }^{16-18}$ but the synthesis of microbial polymer from 1,3-PD is not yet investigated.

\section{EXPERIMENTAL}

\section{Bacterial Strain and Culture Method}

Chromobacterium strain isolated from a soil at Hottate river (Yonezawa city), possessed purple pigment, and was a Gram-negative, aerobic and motile rod. Further, this strain revealed the ability reducing nitrate, oxidase- and catalase-positive, and was confirmed to be fermentative species by Hugh-Leifson method. ${ }^{19}$ The identification tests of the isolated strain by using API 20NE test kit ${ }^{20}$ exhibited some comparable behaviors to Chromobacterium violaceum, but this strain was different from it in several phenotypic properties examined. For example, Chromobacterium violaceum can use mannose as sole carbon source, but the isolated strain is unable to utilize it. In addition, it has been reported that Chromobacterium violaceum cannot accumulate the polyester from heptanoic acid, octanoic acid and 4-hydroxybutanoic acid as a sole carbon source, ${ }^{21}$ while the isolated bacterial strain is capable of accumulating the polyester from above-mentioned each carbon source.

The microbial polyester synthesis from 1,3-PD was carried out by two-stage fermentation. Chromobacterium strain was first grown under aerobic conditions at $30^{\circ} \mathrm{C}$ and $\mathrm{pH} 7.0$ for $24 \mathrm{~h}$ on a reciprocal shaker in a $500 \mathrm{~mL}$ Sakaguchi flask containing $100 \mathrm{~mL}$ of nutrient-rich medium consisting of $1 \mathrm{~g}$ of yeast extract, $1 \mathrm{~g}$ of polypeptone, $0.5 \mathrm{~g}$ of meat extract, and $0.5 \mathrm{~g}$ of $\left(\mathrm{NH}_{4}\right)_{2} \mathrm{SO}_{4}$. The cells were harvested by centrifugation at $5000 \mathrm{~g}$ for $15 \mathrm{~min}$. Under these culture conditions, accumulation of polyester in the cells was not observed. About $0.30 \mathrm{~g}$ quantities of the centrifuged cell of the seed culture were transferred into $100 \mathrm{~mL}$ of mineral medium ( $\mathrm{pH} 7.0$ ) containing $0.265 \mathrm{~g}$ of $\mathrm{KH}_{2} \mathrm{PO}_{4}, 0.380 \mathrm{~g}$ of $\mathrm{Na}_{2} \mathrm{HPO}_{4} \cdot 12 \mathrm{H}_{2} \mathrm{O}, 0.012 \mathrm{~g}$ of $\mathrm{MgSO}_{4}$ and $0.1 \mathrm{~mL}$ of a microelement solution. The micloelement solution contained $2.78 \mathrm{~g}$ of $\mathrm{FeSO}_{4} \cdot 7$ $\mathrm{H}_{2} \mathrm{O}, 1.68 \mathrm{~g}$ of $\mathrm{CaCl}_{2} \cdot 2 \mathrm{H}_{2} \mathrm{O}, 2.81 \mathrm{~g}$ of $\mathrm{CoSO}_{4} \cdot 7 \mathrm{H}_{2} \mathrm{O}$, $0.17 \mathrm{~g}$ of $\mathrm{CuCl}_{2} \cdot 2 \mathrm{H}_{2} \mathrm{O}, 1.98 \mathrm{~g}$ of $\mathrm{MnCl}_{2} \cdot 4 \mathrm{H}_{2} \mathrm{O}$ and $0.29 \mathrm{~g}$ of $\mathrm{ZnSO}_{4} \cdot 7 \mathrm{H}_{2} \mathrm{O}$ (per liter of $1 \mathrm{~N} \mathrm{HCl}$ ). The prescribed amounts of 1,3-PD were added to the mineral medium and the cells were cultivated in these medium for $24-144 \mathrm{~h}$ at $30^{\circ} \mathrm{C}$, After cultivation, the cells were harvested by centrifugation and then lyophilized. Polyesters were extracted from the lyophilized cells with hot chloroform in a Soxhlet apparatus. Chloroform was evaporated in vacuo and residual polymers were separated into $n$-hexane-soluble and $n$-hexaneinsoluble polymers. Each polymer was washed thoroughly with methanol.

\section{Measurements}

The compositions and sequence distributions of copolymers were determined by analyses of ${ }^{1} \mathrm{H}$ and ${ }^{13} \mathrm{C}$ NMR spectra. ${ }^{1} \mathrm{H}$ NMR and ${ }^{13} \mathrm{C}$ NMR analyses were carried out on a JEOL GX-270 spectrometer. The $270-\mathrm{MHz}^{1} \mathrm{H}$ NMR spectra were recorded at $21.3^{\circ} \mathrm{C}$ in a $\mathrm{CDCl}_{3}$ solution of polyester $\left(4 \mathrm{mg} \mathrm{mL}^{-1}\right)$ with a $4.9 \mu$ s pulse width, 16000 data points, and 32 accumulations. The $67.5-\mathrm{MHz}^{13} \mathrm{C}$ NMR spectra were recorded at $21.3^{\circ} \mathrm{C}$ in a $\mathrm{CDCl}_{3}$ solution of polyester $\left(20 \mathrm{mg} \mathrm{mL}^{-1}\right)$ with a $4.0 \mu \mathrm{s}$ pulse width $\left(45^{\circ}\right.$ pulse angle), $3 \mathrm{~s}$ pulse repetition, $20000 \mathrm{~Hz}$ spectral width, 32000 date points, and 15000 accumulations. Tetramethylsilane $\left(\mathrm{Me}_{4} \mathrm{Si}, \delta=0\right)$ was used as an internal chemical shift standard. To determine the composition of $n$-hexane-soluble polyesters, $5 \mathrm{mg}$ of dry polyester sample was subjected to methanolysis with a solution consisting of $1.7 \mathrm{~mL}$ of methanol, $0.3 \mathrm{~mL}$ of $98 \%$ sulfuric acid and $2 \mathrm{~mL}$ chloroform at $100^{\circ} \mathrm{C}$ for $140 \mathrm{~min}$ to convert the constituents to their methyl esters. ${ }^{22}$ Addition of $2 \mathrm{~mL}$ of water to the reaction mixture induced phase separation. The lower chloroform layer was used for gas chromatography (GC) analysis on a Shimadzu GC-14A system equipped with NEUTRA BOND-1 capillary column $(30 \mathrm{~m} \times 0.25 \mathrm{~mm}$, I.D. $0.4 \mu \mathrm{m})$ and a flame ionization detector.

Molecular weights were determined by gel permeation chromatography (GPC) using polystyrene calibration on a JASCO 807-IT equipped with a TOSOH TSK-GEL G4000HXL column at $25^{\circ} \mathrm{C}$ in $\mathrm{CHCl}_{3}$. Sample concentration was $1.0 \mathrm{mg} \mathrm{mL}^{-1}$ and a flow rate of chloroform was $1 \mathrm{~mL} \mathrm{~min}{ }^{-1}$.

Differential scanning calorimetry (DSC) data of polyesters were analyzed in the temperature range of -100 to $200^{\circ} \mathrm{C}$ on a SEIKO SSC 5000 DSC 220 equipped with a cooling acccessory under a nitrogen flow of $30 \mathrm{~mL} \mathrm{~min}{ }^{-1}$. Samples were heated from 0 to $200^{\circ} \mathrm{C}$ at a rate of $20^{\circ} \mathrm{C} \mathrm{min}^{-1}$ under nitrogen stream. The melting temperature $\left(T_{\mathrm{m}}\right)$ and the entalpy of fusion $\left(\Delta H_{\mathrm{m}}\right)$ were determined from the DSC endotherms. For measurement of the glass-transition temperature $\left(T_{\mathrm{g}}\right)$, the samples were maintained at $200^{\circ} \mathrm{C}$ for $1 \mathrm{~min}$, and then rapidly quenched at $-100^{\circ} \mathrm{C}$, They were then heated from $-100^{\circ} \mathrm{C}$ to $200^{\circ} \mathrm{C}$ at a heating rate of $20^{\circ} \mathrm{C} \mathrm{min}^{-1}$. The $T_{\mathrm{g}}$ was taken as the midpoint of the heating capacity change. 
Table I. Biosynthesis of polyesters from 1,3-propanediol (1,3-DP) by Chromobacterium sp. at $\mathrm{pH} 7.0$ and $30^{\circ} \mathrm{C}$ for $96 \mathrm{~h}$

\begin{tabular}{|c|c|c|c|c|c|}
\hline \multirow{3}{*}{$\begin{array}{c}\text { Sample } \\
\text { no. }\end{array}$} & \multirow{3}{*}{$\begin{array}{l}1,3-\mathrm{PD} \\
\text { conc. } \\
\mathrm{g} \mathrm{L}^{-1}\end{array}$} & \multirow{3}{*}{$\begin{array}{l}\text { Cell dry } \\
\text { weight } \\
\mathrm{g} \mathrm{L}^{-1}\end{array}$} & \multirow{3}{*}{$\begin{array}{c}\text { Polyester } \\
\text { content }^{\mathrm{a}}\end{array}$} & \multicolumn{2}{|c|}{ Polyester fraction / wt $\%$} \\
\hline & & & & \multirow{2}{*}{$\begin{array}{l}\text { hexane- } \\
\text { insoluble }\end{array}$} & \multirow{2}{*}{$\begin{array}{l}\text { hexane- } \\
\text { soluble }\end{array}$} \\
\hline & & & & & \\
\hline 1 & 5 & 3.14 & 0.3 & 100 & 0 \\
\hline 2 & 10 & 3.36 & 3.0 & 70 & 30 \\
\hline 3 & 20 & 3.46 & 7.2 & 80 & 20 \\
\hline 4 & 30 & 4.48 & 8.3 & 59 & 41 \\
\hline 5 & 40 & 6.48 & 6.6 & 93 & 7 \\
\hline 6 & 50 & 4.03 & 5.7 & 95 & 5 \\
\hline
\end{tabular}

${ }^{\text {a}}$ Polyester content in cell dry weight.

Table II. Effect of cultivation times on biosynthesis of polyesters from medium containing 1,3-propanediol $\left(30 \mathrm{~g} \mathrm{~L}^{-1}\right)$ by Chromobacterium sp. at $\mathrm{pH} 7.0$ and $30^{\circ} \mathrm{C}$

\begin{tabular}{|c|c|c|c|c|c|}
\hline \multirow{3}{*}{$\begin{array}{c}\text { Sample } \\
\text { no. }\end{array}$} & \multirow{2}{*}{$\begin{array}{c}\text { Cultivation } \\
\text { time } \\
\end{array}$} & \multirow{2}{*}{$\begin{array}{l}\text { Cell dry } \\
\text { weight } \\
\end{array}$} & \multirow{2}{*}{$\begin{array}{l}\text { Polyester } \\
\text { content } \mathrm{t}^{\mathrm{a}}\end{array}$} & \multicolumn{2}{|c|}{ Polyester fraction / wt $\%$} \\
\hline & & & & hexane- & hexane- \\
\hline & $\mathrm{h}$ & $\mathrm{g} \mathrm{L}^{-1}$ & $\mathrm{wt} \%$ & insoluble & soluble \\
\hline 7 & 24 & 3.24 & 0.3 & 100 & 0 \\
\hline 8 & 48 & 3.38 & 1.5 & 78 & 0 \\
\hline 9 & 72 & 3.75 & 4.2 & 72 & 28 \\
\hline 4 & 96 & 4.48 & 8.3 & 59 & 41 \\
\hline 10 & 120 & 3.30 & 9.7 & 90 & 10 \\
\hline 11 & 144 & 2.88 & 6.9 & 93 & 7 \\
\hline
\end{tabular}

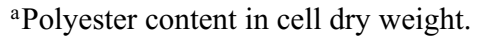

\section{RESULTS AND DISCUSSION}

Table I shows the results of the polyester production in Chromobacterium sp. from different concentrations of 1,3-PD. The cell dry weights increased with the concentration up to $40 \mathrm{~g} \mathrm{~L}^{-1}$ of 1,3-PD, and even $50 \mathrm{~g} \mathrm{~L}^{-1}$ of initial 1,3-PD concentration exhibited scarcely cellular toxicity. The polyester accumulation is observed when the cultivation medium contains an excess of 1,3PD $\left(>10 \mathrm{~g} \mathrm{~L}^{-1}\right)$. When cultivated on medium containing $30 \mathrm{~g} \mathrm{~L}^{-1}$ of 1,3-PD for $96 \mathrm{~h}$, the content of polymers in cell dry weight was $8.3 \mathrm{wt} \%$ and the fractions of $n$ hexane-soluble and insoluble polymers were obtained at $41 \mathrm{wt} \%$ and $59 \mathrm{wt} \%$, respectively. The $n$-hexanesoluble polymer was accumulated most at concentration of $30 \mathrm{~g} \mathrm{~L}^{-1}$ of 1,3-DP. Table II shows the effect of cultivation time on the production of polyester blends from a medium containing $30 \mathrm{~g} \mathrm{~L}^{-1}$ of 1,3-PD in Chromobacterium sp. cells. The polyesters were little produced in Chromobacterium sp. cell during cultivation time of $48 \mathrm{~h}$, but accumulated up to $9.7 \mathrm{wt} \%$ in cell dry weight after $72 \mathrm{~h}$ of cultivation. The $n$-hexane-soluble part was the most mainly produced from medium containing $30 \mathrm{~g} \mathrm{~L}^{-1}$ of 1,3-DP during $96 \mathrm{~h}$ of cultivation. In the culture over $120 \mathrm{~h}$, the accumulation of polymers decreased, this was due to decompose polyesters in the intracellular. The ${ }^{1} \mathrm{H}$ NMR and ${ }^{13} \mathrm{C}$ NMR spectra

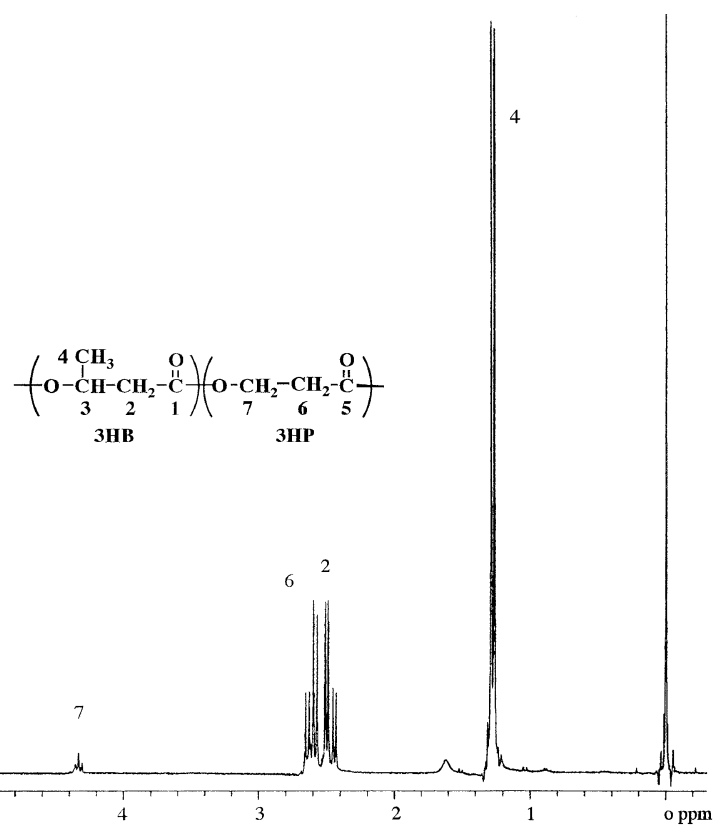

Figure 1. ${ }^{1} \mathrm{H}$ NMR spectrum of $n$-hexane-insoluble polymer of sample 4 in $\mathrm{CDCl}_{3}$.

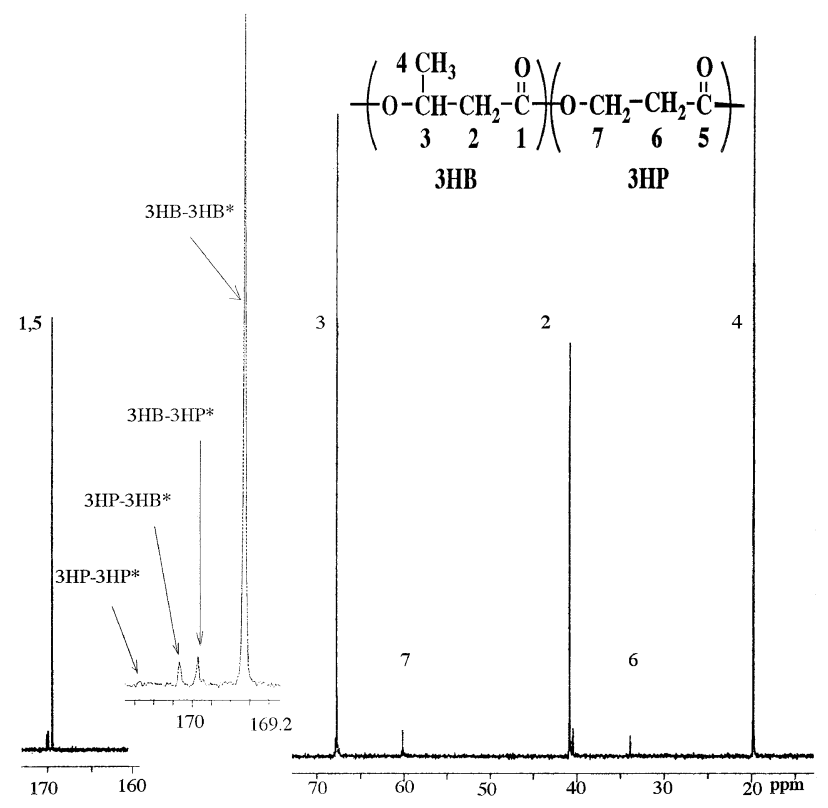

Figure 2. ${ }^{13} \mathrm{C}$ NMR spectrum of $n$-hexane-insoluble polymer of sample 4 in $\mathrm{CDCl}_{3}$.

of $n$-hexane-insoluble and soluble polymers produced from 1,3-PD in Chromobacterium sp. cells show in Figures 1, 2 and Figures 3, 4 respectively, together with the chemical-shift assignments for all proton and carbon resonances. The $n$-hexane-insoluble polymers are composed of two monomeric units of $3 \mathrm{HB}$ and $3 \mathrm{HP}$ by comparing with ${ }^{1} \mathrm{H}$ NMR and ${ }^{13} \mathrm{C}$ NMR spectra data reported by Doi et al. ${ }^{23,24}$ While, the monomeric unit compositions for $n$-hexane-soluble polymers were similar to those analyzed by Huijiberts et al. ${ }^{25}$ and Kato et $a l .{ }^{26}$ for the PHA isolated from Pseudomonas strains grown on carbohydrates. That is, from ${ }^{1} \mathrm{H}$ NMR of 


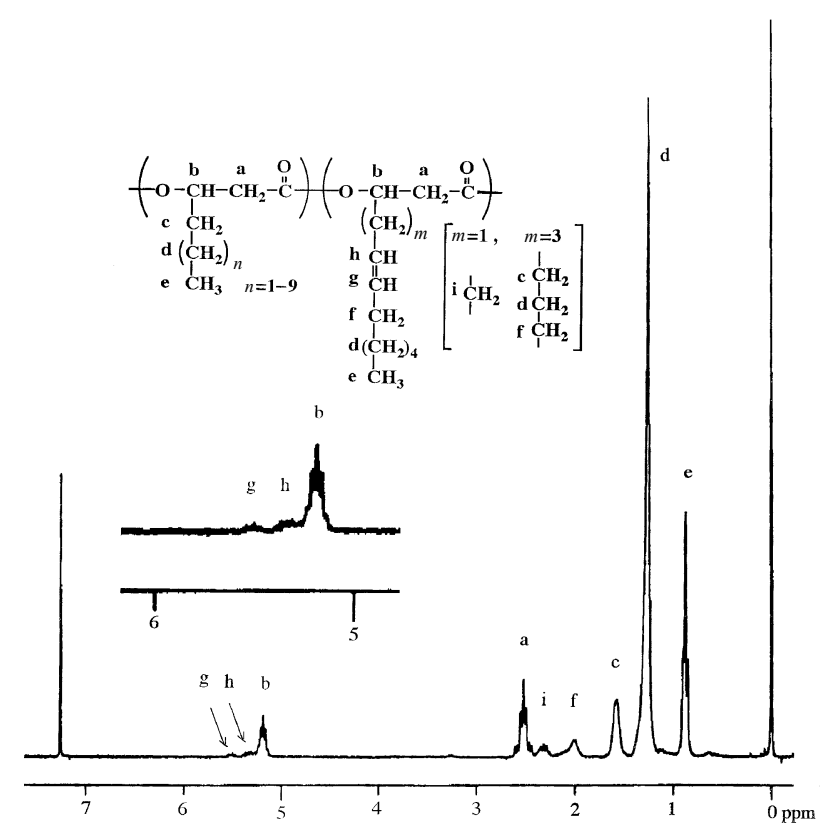

Figure 3. ${ }^{1} \mathrm{H}$ NMR spectrum of $n$-hexane-soluble polymer of sample 4 in $\mathrm{CDCl}_{3}$.

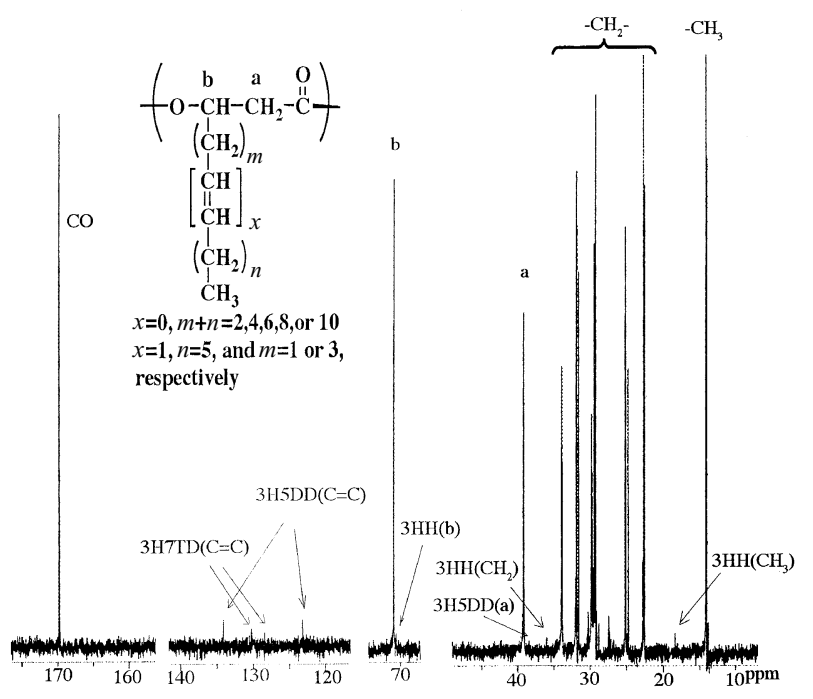

Figure 4. ${ }^{13} \mathrm{C}$ NMR spectrum of $n$-hexane-soluble polymer of sample 4 in $\mathrm{CDCl}_{3}$. Abbreviations of 3HH, 3H5DD, and 3H7TD see footnote in Table III.

$n$-hexane-soluble polymer in Figure 3 the two maltiplet peaks ( $\mathrm{g}$ and $\mathrm{h}$ ) at 5.3 and $5.5 \mathrm{ppm}$ indicate the presence of an unsaturated groups and the peak (b) at $5.2 \mathrm{ppm}$ is assigned to methine proton next to the hydroxy group; peak (i) at $2.3 \mathrm{ppm}$, to the methylene protons between the hydroxyl group and a double bond; peak (f) at $2.1 \mathrm{ppm}$, to the methylene protons next to a double bond, and the peak (c) at $1.6 \mathrm{ppm}$, to the first methylene protons of a saturated alkane side chain. Further, the $67.5 \mathrm{MHz}{ }^{13} \mathrm{C}$ NMR spectra of $n$-hexanesoluble polymer in Figure 4, the small four peaks in the rigion between 123 and $135 \mathrm{ppm}$ provided evidence for the presence of the two unsaturated 3HA monomer units: 3-hydroxy-5-cis-dodecenate (3H5DD) and 3hydroxy-7-cis-tetradecenoate (3H7TD), by comparing with the ${ }^{13} \mathrm{C}$ NMR spectrum of the literature. ${ }^{26}$ The compositions of $n$-hexane-soluble and insoluble polymers produced in different concentrations and culture times were determined from ${ }^{1} \mathrm{H}$ NMR and gas chromatography (GC) analyses, and the results showed in Table III. The compositions of $n$-hexane-soluble and insoluble polymers hardly changed by the concentration of 1,3-PD (from sample 1 to 6 ) and the cultivation time (sample 4, 9, and 11). The 3HP fraction of $n$-hexane insoluble polymer was $6 \mathrm{~mol} \%$ at most. While, the most predominant component of $n$-hexanesoluble polymer was 3-hydroxydecanoate (3HD) and the unsaturated 3HA monomer component was minor at $4 \%$ or less in either under culture condition. Table IV shows the molecular weights and thermal properties of $n$-hexane-soluble and insoluble polymers produced under different cultivation concentrations and times. The molecular weights $\left(M_{\mathrm{n}}\right)$ of $n$-hexane-insoluble polymers were larger than those of soluble polymers, but the molecular weight distributions of both polymers were unimodal and their polydispersities $\left(M_{\mathrm{w}} / M_{\mathrm{n}}\right)$ were in the range of 2.3-2.9, regardless of caltivation conditions. Either $n$-hexane-soluble polymers or insoluble polymesr had a single glass-transition temperature $\left(T_{\mathrm{g}}\right)$ and the melting point $\left(T_{\mathrm{m}}\right)$. The $T_{\mathrm{g}}$ and $T_{\mathrm{m}}$ values of $n$-hexane-soluble polymers were around $-45^{\circ} \mathrm{C}$ and $50^{\circ} \mathrm{C}$, while those of insoluble polymers were around $3^{\circ} \mathrm{C}$ and $150^{\circ} \mathrm{C}$, respectively. The $T_{\mathrm{g}}$ and $T_{\mathrm{m}}$ values of $\mathrm{P}(3 \mathrm{HB}-\mathrm{co}-3 \mathrm{HP})$ with $6 \mathrm{~mol} \% 3 \mathrm{HP}$ fraction were lower than those of $\mathrm{P}(3 \mathrm{HB})$ homopolymer about $2^{\circ} \mathrm{C}$ and $30^{\circ} \mathrm{C}$, respectively. In contrast, the $T_{\mathrm{g}}$ and $T_{\mathrm{m}}$ values of $n$-hexane-soluble polymers were almost equal

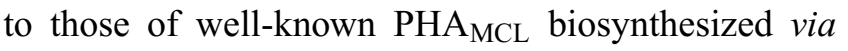
$\beta$-oxidation cycles from medium chain saturated fatty acids. ${ }^{27}$ That $\mathrm{PHA}_{\mathrm{MCL}}$ containing saturated and unsaturated medium alkyl chain units produced in Chromobacterium sp. from 1,3-PD has the melting point is contrast to that produced in Pseudomonas strain from sugars being amorphous. ${ }^{26}$ The monomer dyad sequence distributions of $n$-hexane-insoluble copolyester $\mathrm{P}(3 \mathrm{HB}-$ co-3HP) are given also in Table IV. The diad sequence distribution data for two monomeric units were determined from the relative peak areas of four peaks in the expanded spectra of carbonyl carbon resonances at $169-170.5 \mathrm{ppm}$ in the ${ }^{13} \mathrm{C}$ NMR spectra (Figure 2). The resolved four peaks have been arisen from different diad sequences of connecting $3 \mathrm{HB}$ and $3 \mathrm{HP}$ units. $^{24}$ The diad sequence distribution data were compared with the Bernoullian statistics applicable to a statistically random copolymerization. ${ }^{28}$ In the Bernoullian model, the mole fraction $F_{\mathrm{ij}}$ of diad sequence $i j$ can 
Table III. Compositions of $n$-hexane-soluble and insoluble polymers produced from 1,3-PD by Chromobacterium sp.

\begin{tabular}{|c|c|c|c|c|c|c|c|c|c|c|c|}
\hline \multirow{2}{*}{$\begin{array}{c}\text { Sample } \\
\text { no. }\end{array}$} & \multirow{2}{*}{ Polyester } & \multirow{2}{*}{$\frac{\text { Fraction weight }}{\mathrm{mg} \mathrm{L}^{-1}}$} & \multicolumn{9}{|c|}{ Polyester composition ${ }^{\mathrm{a}} / \mathrm{mol} \%$} \\
\hline & & & $3 \mathrm{HB}$ & $3 \mathrm{HP}$ & $3 \mathrm{HH}$ & $3 \mathrm{HO}$ & $3 \mathrm{HD}$ & 3HDD & 3H5DD & 3HTD & 3H7TD \\
\hline \multirow{2}{*}{1} & soluble & 0 & - & - & - & - & - & - & - & - & - \\
\hline & insoluble & 9 & 98 & 2 & 0 & 0 & 0 & 0 & 0 & 0 & 0 \\
\hline \multirow{2}{*}{2} & soluble & 28 & - & - & - & - & - & - & - & - & $-^{b}$ \\
\hline & insoluble & 71 & 97 & 3 & 0 & 0 & 0 & 0 & 0 & 0 & 0 \\
\hline \multirow{2}{*}{3} & soluble & 50 & 0 & 0 & 6 & 28 & 61 & 3 & 2 & 0 & 0 \\
\hline & insoluble & 199 & 96 & 4 & 0 & 0 & 0 & 0 & 0 & 0 & 0 \\
\hline \multirow{2}{*}{4} & soluble & 152 & 0 & 0 & 4 & 26 & 59 & 4 & 2 & 4 & 1 \\
\hline & insoluble & 219 & 94 & 6 & 0 & 0 & 0 & 0 & 0 & 0 & 0 \\
\hline \multirow[b]{2}{*}{5} & soluble & 30 & - & - & - & - & - & - & - & - & $-^{\mathrm{b}}$ \\
\hline & insoluble & 398 & 95 & 5 & 0 & 0 & 0 & 0 & 0 & 0 & 0 \\
\hline \multirow{2}{*}{6} & soluble & 11 & - & - & - & - & - & - & - & - & $-^{\mathrm{b}}$ \\
\hline & insoluble & 218 & 98 & 2 & 0 & 0 & 0 & 0 & 0 & 0 & 0 \\
\hline \multirow{2}{*}{9} & soluble & 44 & 0 & 0 & 4 & 24 & 58 & 5 & 3 & 5 & 1 \\
\hline & insoluble & 113 & 94 & 6 & 0 & 0 & 0 & 0 & 0 & 0 & 0 \\
\hline \multirow{2}{*}{11} & soluble & 18 & - & - & - & - & - & - & - & - & $-^{\mathrm{b}}$ \\
\hline & insoluble & 180 & 98 & 4 & 0 & 0 & 0 & 0 & 0 & 0 & 0 \\
\hline
\end{tabular}

${ }^{\mathrm{a}}$ Determined by ${ }^{1} \mathrm{H}$ NMR and GC: 3HB; 3-hydroxybutyrate, 3HP; 3-hydroxypropionate, 3HH; 3-hydroxyhexanoate, 3HO; 3-hydroxyoctanoate, 3HD; 3-hydroxydecanoate, 3HDD; 3-hydroxydodecanoate, 3H5DD; 3-hydroxy-5-cis-

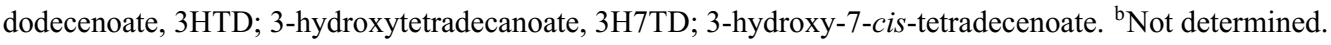

Table IV. Properties of polyesters produced from 1,3-PD by Chromobacterium sp. and dyad sequence distributions of

\begin{tabular}{|c|c|c|c|c|c|c|c|c|c|c|}
\hline \multirow{3}{*}{$\begin{array}{c}\text { Sample } \\
\text { no. }\end{array}$} & \multirow{3}{*}{ Polyester } & \multicolumn{2}{|c|}{ Molecular weight $^{\mathrm{a}}$} & \multicolumn{3}{|c|}{ Thermal properties ${ }^{b}$} & \multirow{2}{*}{\multicolumn{4}{|c|}{$\frac{\text { Dyad fraction of } \mathrm{P}(3 \mathrm{HB}-c o-3 \mathrm{HP})^{\mathrm{c}}}{\mathrm{mol} \%}$}} \\
\hline & & \multirow[t]{2}{*}{$\overline{10^{-4} M_{\mathrm{n}}}$} & \multirow[t]{2}{*}{$\overline{M_{\mathrm{w}} / M_{\mathrm{n}}}$} & \multirow{2}{*}{$\frac{T_{\mathrm{g}}}{{ }^{\circ} \mathrm{C}}$} & \multirow{2}{*}{$\frac{T_{\mathrm{m}}}{{ }^{\circ} \mathrm{C}}$} & \multirow{2}{*}{$\overline{\frac{\Delta H_{\mathrm{m}}}{\mathrm{Jg}^{-1}}}$} & & & & \\
\hline & & & & & & & $\overline{\mathrm{BB}}$ & $\mathrm{BP}$ & PB & $\mathrm{PP}$ \\
\hline \multirow{3}{*}{3} & soluble & 14 & 2.3 & -40 & 48 & 15 & & & & \\
\hline & insoluble & 23 & 2.8 & 4 & 157 & 59 & 93 & 4 & 3 & 0 \\
\hline & & & & & & & $(92.2)$ & (3.8) & (3.8) & 0.2 \\
\hline \multirow{3}{*}{4} & soluble & 12 & 2.6 & -45 & 53 & 18 & & & & \\
\hline & insoluble & 39 & 2.7 & 2 & 148 & 48 & 89.5 & 5 & 5 & 0.5 \\
\hline & & & & & & & $(88.4)$ & $(5.6)$ & $(5.6)$ & $(0.4)$ \\
\hline \multirow{3}{*}{5} & soluble & 10 & 2.9 & -43 & 50 & 17 & & & & \\
\hline & insoluble & 32 & 2.8 & 2 & 148 & 52 & 89 & 6 & 5 & 0 \\
\hline & & & & & & & $(90.2)$ & $(4.8)$ & $(4.8)$ & $(0.2)$ \\
\hline \multirow{3}{*}{6} & soluble & $\mathrm{nd}^{\mathrm{d}}$ & nd & nd & nd & nd & & & & \\
\hline & insoluble & 44 & 2.4 & 4 & 158 & 55 & 97 & 2 & 1 & 0 \\
\hline & & & & & & & $(96.0)$ & $(2.0)$ & $(2.0)$ & $(0.0)$ \\
\hline \multirow{3}{*}{9} & soluble & 9 & 2.5 & -45 & 50 & 18 & & & & \\
\hline & insoluble & 28 & 2.7 & 2 & 150 & 53 & 90 & 5 & 5 & 0 \\
\hline & & & & & & & $(88.4)$ & (5.6) & (5.6) & $(0.4)$ \\
\hline \multirow{3}{*}{11} & soluble & $\mathrm{nd}^{\mathrm{d}}$ & nd & nd & nd & nd & & & & \\
\hline & insoluble & 14 & 2.7 & 3 & 151 & 53 & 92 & 4 & 4 & 0 \\
\hline & & & & & & & $(92.2)$ & (3.8) & (3.8) & $(0.2)$ \\
\hline
\end{tabular}

${ }^{a}$ Determined by GPC. ${ }^{b}$ Measured by DSC. ${ }^{c}$ Determined from relative intensities of carbonyl resonances in ${ }^{13} \mathrm{C}$ NMR spectra. The values in parentheses were calculated by Bernoullian statistics with the mole fraction of $3 \mathrm{HP}$ unit. ${ }^{\mathrm{d}}$ Not determined.

be expressed with the mole fraction $F_{\mathrm{i}}$ and $F_{\mathrm{j}}$ of $i$ and $j$ units as $F_{\mathrm{ij}}=F_{\mathrm{i}} F_{\mathrm{j}}$. As shown in Table IV, the diad fractions $\left(F_{\mathrm{BB}}, F_{\mathrm{BP}}, F_{\mathrm{PB}}\right.$, and $\left.F_{\mathrm{PP}}\right)$ calculated from the mole fractions of $3 \mathrm{HB}$ and $3 \mathrm{HP}$ units are in agreement with the observed values for samples produced under different culture conditions. It is concluded that the sequence distributions of $3 \mathrm{HB}$ and $3 \mathrm{HP}$ units in those samples are statistically random, though the mole fractions of 3HP in copolymers are less than $6 \mathrm{~mol} \%$. Hitherto, $\mathrm{P}(3 \mathrm{HB}-c o-3 \mathrm{HP}) \mathrm{s}$ were produced from 3-hydroxypropionic acid (3HP) or alkanediols of odd carbon number 5 to 7 with Ralstonia eutropha, ${ }^{23}$ and from $3 \mathrm{HP}$ and sucrose as carbon sources with $\mathrm{Al}$ caligenes latus. ${ }^{24}$ but have not been comfirmed to be 


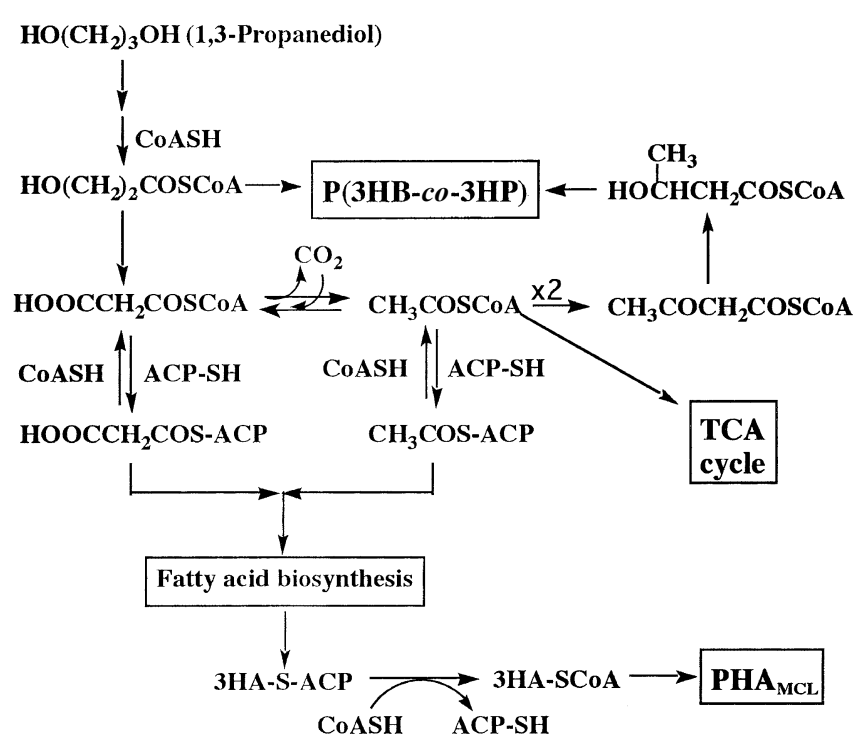

Figure 5. Putative metabolic pathway of $\mathrm{P}(3 \mathrm{HB}-\mathrm{co}-3 \mathrm{HP})$ and $\mathrm{PHA}_{\mathrm{MCL}}$ syntheses from 1,3-propanediol (1,3-PD) in Chromobacterium sp. TCA cycle, CoASH, and ACP-SH denote the tricarboxylic acid cycle, coenzyme A and acyl carrier protein, respectively.

produced from 1,3-PD by those bacteria. As 1,3-PD is cheap and renewable carbon source, it is interesting that $\mathrm{P}(3 \mathrm{HB}-c o-3 \mathrm{HP})$ was biosynthesized from 1,3-PD by Chromobacterium sp., even though the yield of this copolyester was low. It is recently reported that 1,3-PD can be produced by some kind of microorganism from glycerol ${ }^{9}$ and glucose ${ }^{10}$ as natural products. Then, we conducted out the cultivation of Chromobacterium sp. in medium containing glycerol or glucose as a sole carbon source. As a result, only $\mathrm{P}(3 \mathrm{HB})$ homopolymer was produced from each carbon source at yield up to $22 \mathrm{wt} \%$ of the dry cell matters, but neither P(3HBco-3HP) nor $n$-hexane-soluble polyester was obtained. This suggests that there is no ability in which Chromobacterium sp. dissimilates glycerol or glucose to 1,3-PD.

Figure 5 shows a putative metabolic pathway of the biosynthesis of the blend of P(3HB-co$3 \mathrm{HP}$ ) and $\mathrm{PHA}_{\mathrm{MCL}}$ containing the saturated and unsaturated 3HA units from 1,3-PD in Chromobacterium sp. When 1,3-PD is used as the sole carbon source, 3-hydroxypropionyl-coenzyme $\mathrm{A}(\mathrm{CoA})$ is first formed in the cells via the oxidation of 1,3-PD by a dehydrogenase. Additional oxidation of most of 3-hydroxypropionyl-CoA may generate malonylCoA that by decarboxylase convert into acetylCoA. The acetyl-CoA is condensed by 3-ketothiolase to give acetoacetyl-CoA that is reduced to $(R)-3-$ hydroxybutyryl-CoA. A random copolyester of $3 \mathrm{HB}$ and $3 \mathrm{HP}$ units may be produced by polymerization of (R)-3-hydroxybutyryl-CoA with 3-hydroxypropionyl-
CoA under the action of a synthase. While, the pathway of biosynthesis of $\mathrm{PHA}_{\mathrm{MCL}}$ with two unsaturated monomeric units from 1,3-PD may suggest possible linkage of de novo fatty acid biosynthesis, that involve the formation of $(R)$-3-hydroxyacyl-ACP (acyl carrier protein) with even carbon number of 4 to 14 constituents from acetyl-CoA and malonyl-CoA as starting materials. ${ }^{29}$ The (R)-3-hydroxyacyl-ACP intermediates may be converted into $(R)$-3-hydroxyacyl-CoA, that is polymerized to give $\mathrm{PHA}_{\mathrm{MCL}}$ by a different synthase with it of $\mathrm{P}(3 \mathrm{HB}-\mathrm{co}-3 \mathrm{HP})$ biosynthesis as well as being reported by Kato et al. ${ }^{26}$ The production of PHA $\mathrm{MCL}$ was dependent on the concentration of 1,3-PD as shown in Table I. This observation may be relation with being the concentration of 1,3-PD of a limiting level such that induces the generation of malonyl-ACP in Chromobacterium sp. cells. However, it seems to not yet examine such fact in detail in other microorganism producing the $\mathrm{PHA}_{\mathrm{MCL}}$ by de novo fatty biosynthesis. The biosynthesis of $\mathrm{PHA}_{\mathrm{MCL}}$ via de novo fatty acid biosynthesis is known to occur solely in psuedomonads belonging to rRNA homology group $\mathrm{I},{ }^{30}$ and recently reported to result in the diversion of (R)-3-hydroxyacyl-ACP to $(R)$-3-hydroxyacyl-CoA by transacylase PhaG, followed by the polymerization into $\mathrm{PHA}_{\mathrm{MCL}}$ by synthase PhaC. ${ }^{3,31}$ Therefore, it is noteworthy that Chromobacterium sp. except psuedomonad strains has produced simultanously both $\mathrm{P}(3 \mathrm{HB}-c o-3 \mathrm{HP})$ as $\mathrm{PHA}_{\mathrm{SCL}}$ and $\mathrm{PHA}_{\mathrm{MCL}}$. Additional studies on the detailed biosynthesis conditions and pathway of PHAs from 1,3-PD by this Chromobacterium sp. are in progress.

In conclusion, it has been demonstrated that a new Chromobacterium strain can produce a blend of $\mathrm{P}(3 \mathrm{HB}-\mathrm{co}-3 \mathrm{HP})$ and $\mathrm{PHA}_{\mathrm{MCL}}$ containing the saturated $3 \mathrm{HA}$ units of even carbon numbers $\mathrm{C} 6$ to $\mathrm{C} 14$ in addition to two unsaturated 3HA units of $\mathrm{C} 12$ and $\mathrm{C} 14$ when cultivated on 1,3-PD as sole carbon source under nitrogen-limited condition.

Acknowledgments. We are indebted to Professor Yoshiharu Doi of Tokyo Institute of Technology for valuable suggestions on biosynthesis of polyesters. This study has been supported by CREST (Core Research for Evolutional Science and Technology) of Japan Science and Technology Corporation. (JST).

\section{REFERENCES}

1. A. J. Anderson and E. A. Dawes, Microbiol. Rev., 54, 450 (1990).

2. K. Sudesh, H. Abe, and Y. Doi, Prog. Polym. Sci., 25, 1503 (2000).

3. B. H. A. Rehm, T. A. Mitsky, and A. Steinbüchel, Appl. Env- 
iron. Microbiol., 67, 3102 (2001).

4. P. A. Holmes, Phys. Technol., 16, 32 (1985).

5. N. D. Miller and D. F. Williams, Biomaterials, 8, 129 (1987).

6. A. Timm and A. Steinbüchel, Appl. Environ. Microbiol., 56, 3360 (1990).

7. A. Steinbüchel, "Biomaterials," D. Byrom, Ed., Macmillan Publishers, Basingstoke, 1991, p 123.

8. Y. Doi, A. Segawa, and M. Kunioka, Int. J. Biol. Macromol., 12, 106 (1990).

9. H. Mitomo, N. Morishita, and Y. Doi, Macromolecules, 26, 5809 (1993).

10. N. Yoshie, H. Menju, H. Sato, and Y. Inoue, Macromolecules, 28, 6516 (1995).

11. E. Y. Lee, D. Jendrossek, A. Schirimer, C. Y. Choi, and A. Steinbüchel, Appl. Microbiol. Biotechnol., 42, 901 (1995).

12. M. Kato, T. Fukui, and Y. Doi, Bull. Chem. Soc. Jpn., 69, 515 (1996).

13. H. Matsusaki, S. Manji, K. Taguchi, M. Kato, T. Fukui, and Y. Doi, J. Bacteriol. 180, 6459 (1998).

14. H. Biebl, S. Marten, H. Hippe, and W.-D. Deckwer, Appl. Microbiol. Biotechnol., 36, 592 (1992).

15. P. L. Meredith, J. Polym. Sci., Part A: Polym. Chem., 38, 667 (2000)

16. U. Witt, R.-J. Müller, J. Augusta, and H. Widdecke, Macromol. Chem. Phys., 195, 793 (1994).

17. E. Ranucci, Y. Liu, M. S. Lindblad, and A.-C. Albertsson,
Macromol. Rapid. Commun., 21, 680 (2000).

18. Y. Liu, E. Ranucci, M. S. Lindblad, and A.-C. Albertsson, J. Polym. Sci., Part A: Polym. Chem., 39, 2508 (2001).

19. R. Hugh and E. Leifson, J. Bacteriol., 66, 24 (1953).

20. API $20 \mathrm{NE}$ that is test kit for identification of gram-negative bacteria was purchaced from bioMérieux-Vitek Japan, Ltd.

21. A. Steinbüchel, EI-M. Debzi, R. H. Marchessault, and A. Timm, Appl. Microbiol. Biotechnol. 39, 443 (1993).

22. H. Brandl, G. K. Hamer, R. W. Lenz, and R. C. Fuller, Appl. Environ. Microbiol., 54, 1977 (1988).

23. S. Nakamura, M. Kunioka, and Y. Doi, Macromol. Rep., A28, 15 (1991).

24. M. Hiramitsu and Y. Doi, Polymer, 34, 4782 (1993).

25. G. N. M. Huijiberts, G. Eggink, P. de Waard, G. W. Huisman, and B. Witholt, Appl. Environ. Microbiol., 58, 1949 (1992).

26. M. Kato, H. J. Bao, C.-K. Kang, T. Fukui, and Y. Doi, Appl. Microbiol. Biotechnol., 45, 363 (1996).

27. R. A. Gross, C. Demello., R. W. Lenz, H. Brandl, and R. C. Fuller, Macromolecules, 22, 1106 (1989).

28. Y. Doi, M. Kunioka, Y. Nakamura, and K. Soga, Macromolecules, 19, 2860 (1986).

29. Y. Saito and Y. Doi, Int. J. Biol. Macromol., 15, 287 (1993).

30. A. Steinbüchel, "Biotechnology", M, Roehr, Ed., VCH Publishers, New York, N.Y., 1996, p 403.

31. N. Hoffmann, A. Steinbüchel, and B. H. A. Rehm, FEMS Micro. Biol. Lett., 184, 253 (2000). 